\title{
Urban Design Dimension Of Informality At The Perimeter Of Brawijaya University And UIN Maliki Malang
}

\author{
Binar Tyaghita Cesarin ${ }^{1, *}$, Himasari Hanan ${ }^{2}$, and Agus Suharjono Ekomadyo ${ }^{2}$ \\ ${ }^{1}$ Magister Student of Urban Design Department of Architecture, School of Architecture, Planning and Policy Development; Bandung \\ Institute of Technology, Indonesia \\ ${ }^{2}$ Lecturer, Department of Architecture, School of Architecture, Planning and Policy Development, Bandung Institute of Technology, \\ Indonesia
}

\begin{abstract}
Informality is one of the commonly emerged issues in urban design which rarely explored, especially informality within university's perimeter. Brawijaya as one of the biggest and oldest University in Malang over time has boosted the development of several of its perimeter, provided several hotspots for students and youth. These rapid hotspots growth is related to the growth of informal practices. For cities that developed by its universities, it is necessary to understand both of the formal and informal practices within its perimeter. Through this study I would like to know the characteristic of informality within university perimeter, which formed by Brawijaya, UIN Maliki, and ITN; and to frame it within Carmona's Urban Design Dimension. Mapping is utilized as a primary method to analyze both formal and informality within site. The formal aspect consists of formal activities, function and site user. While informality mapper consists of street vendors and street art. The research found that while urban informality within Brawijaya and UIN Maliki are related to the character and morphology, its formal structure has; its relation is reciprocal. The morphological, visual and functional dimension of university perimeter is driven by the social, perceptual and temporal dimension formed by its user and showed through informality.
\end{abstract}

Keywords: University Perimeter, Informality, Street Vendor, Street Art

\section{Introduction}

Informality is one of the commonly emerged issues in urban design which rarely explored, especially informality within university perimeter. University perimeter in Indonesian cities usually grows to support the student life activity which interrelated with the life of its local residents. As informal practice character intermeshed with its formal structure (Dovey, 2012), it is interesting to explore the characteristics of informality within university perimeter.

The complexity and severity of informality cases often made it difficult to understand and manage which explained why the government, planners and urban designer's efforts to manage informality are rarely succeeded. Urban design is integrated design field concerning the urban setting, which is both process and product. With that framework, Carmona et al (2003) proposed six dimension or urban design that are overlapping and interrelated within the everyday urban activity. Framing informality within urban design dimension might provide a new way to understand and manage the urban informality. Which to control and to tolerate; and which to ignore and recognize.

Malang is the second largest city in East Java, Indonesia and currently known as the 'education city' as it has at least 55 higher education institutions including universities. One of its university perimeters is located around the Sumbersari - Gajayana Street. Wedge by three Universities: Brawijaya, UIN Maliki and ITN and consists of two kampongs (Ketawanggede and Sumbersari); this site has the unique characteristic of Indonesia's university perimeter which has a diverse user. Through this study, I would like to understand the characteristics of informality within university perimeter and how to frame it within urban design dimension so that it can be used as consideration for government, planner and urban designer to understand and manage informality, especially within University perimeter.

\section{Understanding Urban Informality}

Informality is actually part of human oldest civilization which organically developed from informal settlement and trading. After 1950 the process is reversed, as informality process started after the formal structure was built. (Dovey, 2016). Informality actually first mentioned by Juan Pablo Pe'rez Sa'inz in 1989, but arguments and concept about informality started to developed in the 1950s. During that period, informality within urban space often associated with immigrants and poverty. Informality refers to certain practices done by groups of people which consist of petty traders, street vendors, coolies and porters, small artisans, messengers, barbers, shoe-shines boys and personal servants at alleyway or street side (Al-Sayyad, 2004 as cited in Dovey,

*Corresponding author: tyaghita@gmail.com 
2016).

Generally during that period urban informality defined as urban practice outside formal planning and regulation which usually done by certain groups of people with limited working and economy capability. However after the 2000s more positive understanding of urban informality started to arise. Al - Sayyad (as cited in Dovey, 2016) defined urban informality as a new way of life, which done to overcome poverty, availability of jobs and settlement which cannot be supplied and/or achieved formally. Informal trading also showed a form of entrepreneurial flexibility, adaptability skills and creativity (Neuwirth, 2012).

Urban informality, especially in form of street vendor, is a widespread phenomenon in Indonesian's city. It is a part of every day's life and can be found where there is a high concentration of population. The existence of street vendor at urban spaces often triggers problems such as traffic congestion, contribute negatively to the physical appearance of urban space, contribute to lack health issues and reduce the feeling of safety amongst the street user. It also considers a threat to local business and often triggers conflict. Although there is also a positive aspect of urban informality which is potential to enrich the character of urban space, enhance the lively atmosphere, animate the life of the city; generally urban informality was considered out of place (Yatmo, 2008).

Street vendors are often characterized by mobility and flexibility. Those aspects manifest into the physical setting of their activity which in Indonesia it mostly consists of stationary with a permanent structure such as warung or kiosk, stationary with non permanent structure that is easily assembled and disassembled such as gelaran or mat and tent, ambulatory by using pushcart, pikulan and bakul (Yatmo, 2008). Mobility and flexibility are the key survival tactic when the informal trader is subject to prosecution and confiscation of goods (Dovey, 2016).

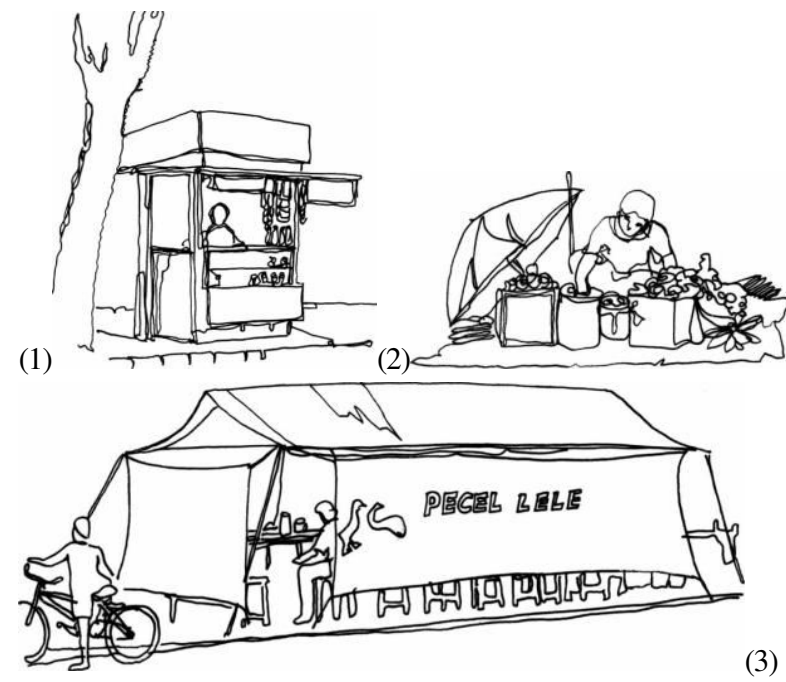

Fig. 1. Types of Street Trading in Indonesia: 1) Kiosk, 2) Mat, 3) Tent.

Source: Yatmo, 2008.

The types of the street vendors are also geared to the urban morphology in subtly different ways. In general terms, the more fixed types are more likely to be tolerated in relatively informal parts of the city, while the more mobile vendors are able to infiltrate the more formal city. The fixed kiosk requires a high level of protection, while mobile traders can more easily escape from street cleaning' operation. The fixed kiosk is essentially a form of informal settlement since a temporal stall can become a permanent building overtime as wheels become dysfunctional and a roof is added. There are also daily and weekly cycle of informal trading, where several enterprises using the same space at different times of the day. Sometimes, the uses of place also show collaboration between traders with adjacent shopkeeper/ shop owner.
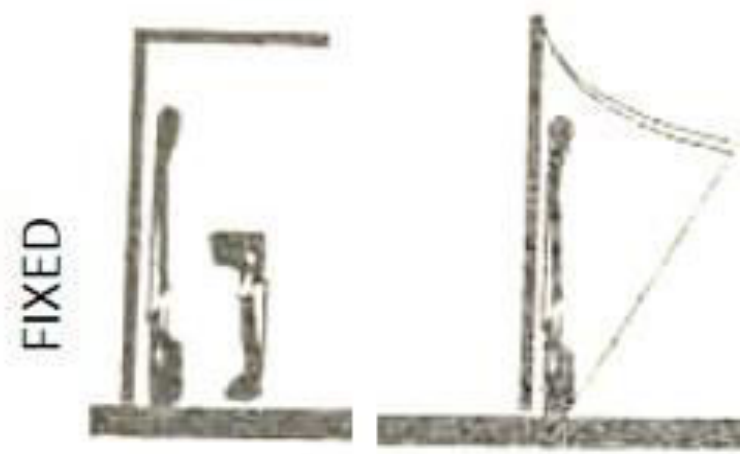

KIOSK.
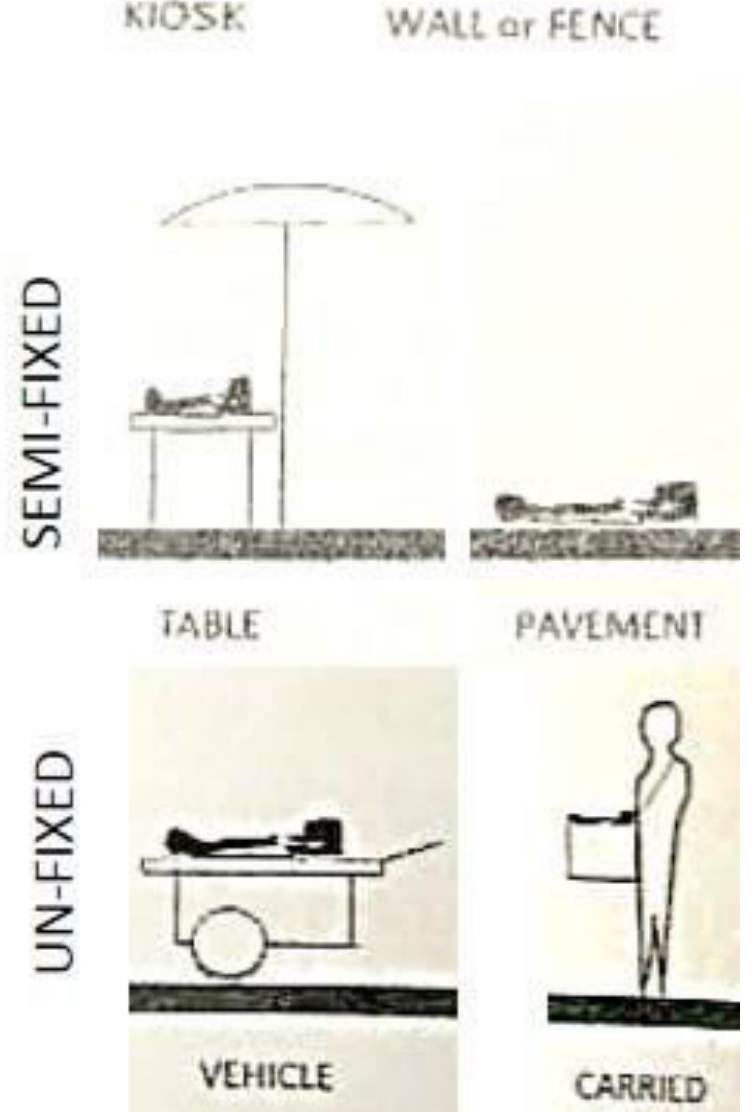

Fig. 2. Spatial Typologies of Street Trading. Source: Dovey, 2016.

Graffiti is also considered an 'out of place' elements of urban design (Cresswell, 1996 in Yatmo, 2008). While it actually the oldest art form with its roots in cave paintings, currently it is a practice that slips between crime and arts 
(Dovey, 2016). The varieties of graffiti writing range from the quick tagging of a signature (in felt pen or spray paint) through various forms of 'paste-ups', slogans, 'throw-ups' and stencils to larger pieces or extended wall.

Urban graffiti is mediated by urban morphology and depends upon the production of blank and relatively smooth public walls that are not strongly identified with the occupants. Grafitti emerges within the interstices of a streetscape, or side or rear walls, laneways, derelict buildings, retaining walls, bridges, and railway cuttings. While laneways are relatively saturated, some main streets are entirely unaffected; where graffiti transgresses an existing identity, then it is much less likely to be produced and much more likely to be erased.

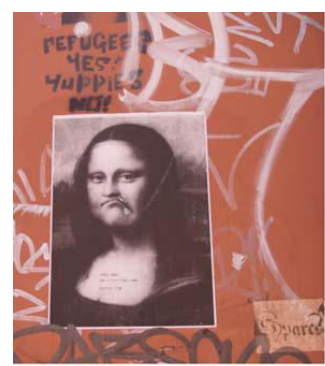

Tags, Paste-up, Stencil

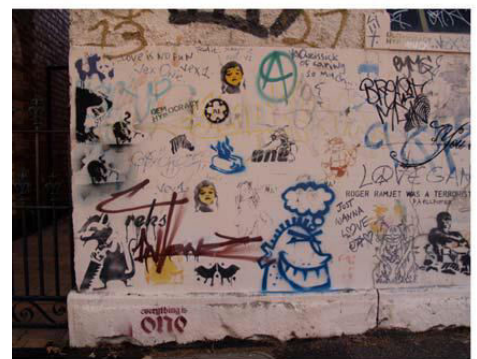

Stencils,Tags, Slogans

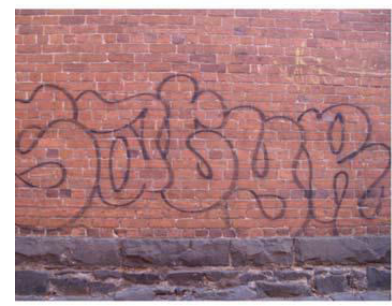

Throw-up

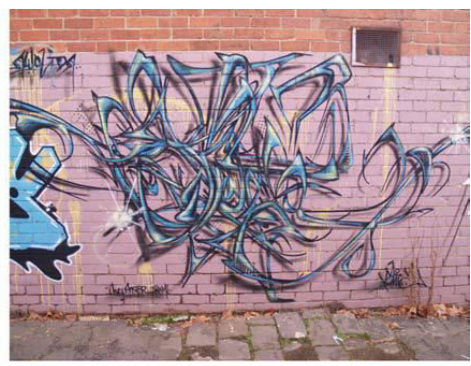

Piece

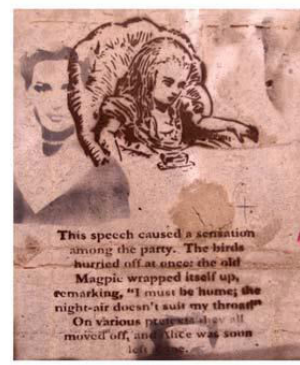

Stencils

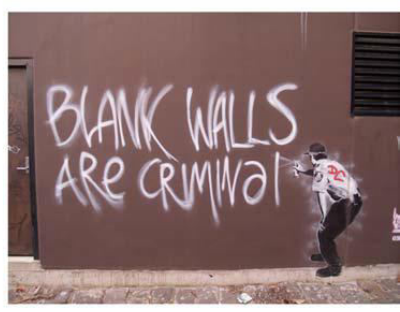

Slogan, Stencil
Fig. 3. Types of Grafitti.

Source: Dovey, 2012.

In locations where dynamism, change and creativity are seen as integral to the emergence of place identity, graffiti is often an important contributor to the production of an edgy and trasgressive urban character (Dovey, Woodcock and Wood 2012). When it's out of place it will considered vandalism, but when it enhance the characteristic of the urban space it considered a street art. It symbolic capital allows a slippage into place branding and advertising, adding economic value to a street art.Street art at its best engages with the street and draws its potency from the urban situation in which it located.
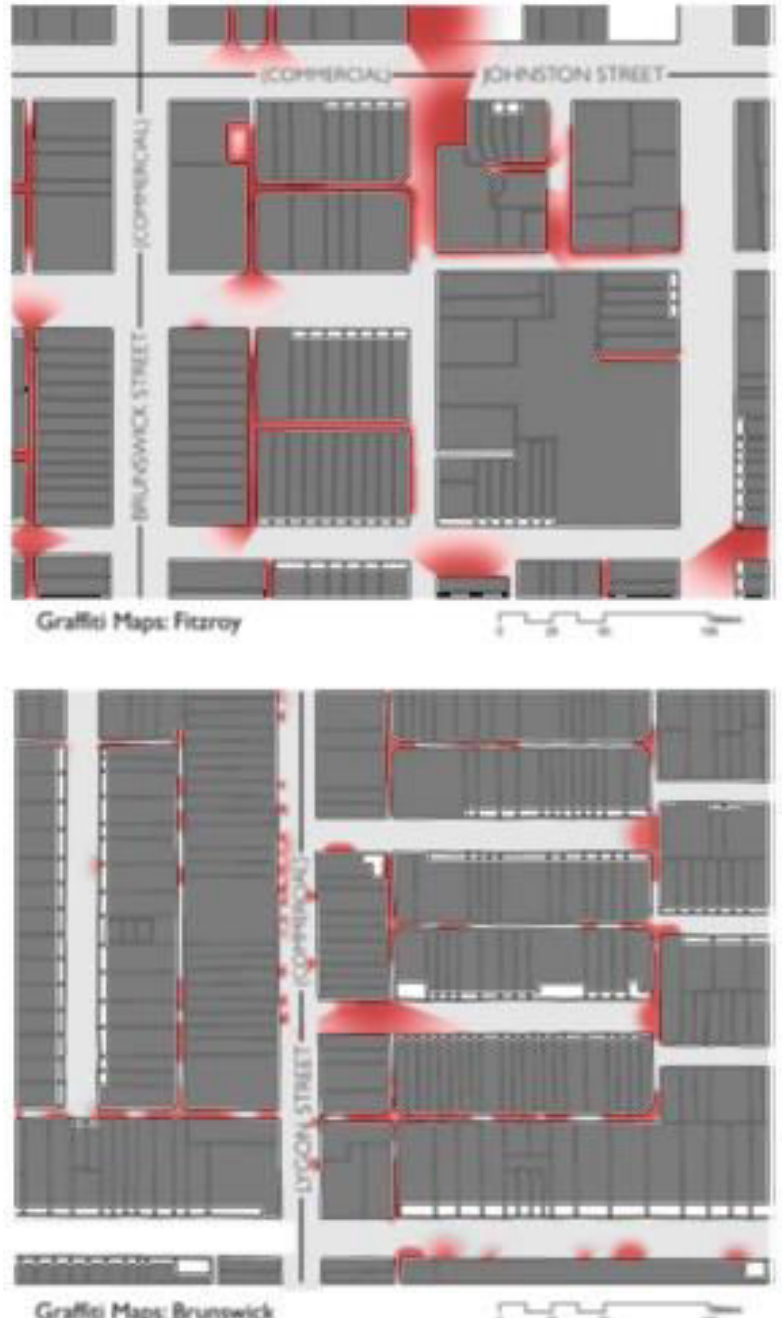

Graflie Maps Brunswick

Fig. 4. Graffiti and morphology in Fitzroy and Brunswick.

Source: Dovey, 2012.

\section{Urban Design Dimension}

Urban design is integrated design field which main concern is public space within urban settings. It is a shared interest between at least city planning, landscape architecture, civil engineering, and architecture field (Carmona et al, 2003; Lang,2005). The concern in Urban Design developed over time, from the visual aesthetic tradition which emphasising the visual qualities of buildings and space during the 1890s 1960s; the social usage tradition which primarily concerned with the social qualities of people, places and activities during 1960s - 1980s; which then fused and developed into the 'making places' tradition.

Through the 'making place' tradition, contemporary urban design simultaneously concerned with both the aesthetic entity and behavioral setting, which shifts the focus of urban design on diversity and activity. With this concept comes the notion of urban design as the design and management of the 'public realm' - defined as the public face of buildings, the spaces between frontages, the activities taking place in and between these spaces, and the managing of these activities, all of which are affected by the uses (Carmona et al, 2003). 
Within the 'making place' tradition, there have been a number of attempts to identify the desirable qualities of successful urban places and/or 'good' urban form by Lynch (1981), Jacobs and Appleyard (1987), Bentley (1985), Tibbalds (1989) and Congress or New Urbanism (1993). Each of those has a different degree of prescription and created with a different context. Urban design dealt with a rapidly changing environment which driven by diverse user and activity, and involve diverse process and field. Thus it is necessary to see urban design as both design process and product (Carmona, et al, 2003; Lang,2005). With that framework, Carmona et al (2003) proposed six dimension or urban design that are overlapping and interrelated within everyday urban activity which consists of morphological, perceptual, social, visual, functional and temporal.

The morphological dimension of urban design mostly focusing on issues of urban form and urban layout regarding permeability, integration, and segregation; and vehicular/pedestrian access. The urban form and layout are formed by land uses, building the structure, plot pattern, street pattern and public space network. Within the urban form and layout, there are parts which do not change or change slowly and the part which changes over a much shorter period of time.

The perceptual dimension of urban design emphasize on people and how they perceive, value, draw meaning from and add meaning to the urban environment. Perception is more than just seeing or sensing the urban environment. It refers to the more complex processing or understanding of stimuli found in the urban environment. The consequences of these process on urban design are the construction of place, which involves the design of land use and built from considering the meaning/image it wants to achieve. One of the current issues found in the urban environment is placelessness which caused by globalization, mass culture and loss of attachment to the territory. The other is invented places which involves superficiality, 'other-directedness' and lacking authenticity.

The social dimension raises issues concerning values and difficult choices with regard to the effect of a design decision on individuals and groups in society. Within social dimension, the boundary of the public realm is often difficult to identify and define precisely. The public realm has 'physical' dimension which is the space and setting that support or facilitates public life; and 'social' dimensions which are the activities and events occurring in those spaces and settings. Because the physical setting is often difficult to identify, it is suggested that urban designer focuses on the social dimension which is the public life. Public life can be broadly grouped into two interrelated types: 'formal' and 'informal'. Of most interest in urban design is informal public life, which occurs beyond the realm of formal institutions and entails choice. The role of design is delivering particular social goals which are the provision of an accessible, safe and secure, equitable public realm for all. For that urban designer will need to work with a wide range of other public and private stakeholders to effect significant sound benefits. Rather than determining human actions or behavior, urban design can be seen as a means of manipulating the probabilities of certain actions or behaviors occurring. While urban designers cannot 'make' places, they can create more 'place potential'.

The visual dimension emphasized the need for the urban designer to consider the whole context in which they approach the visual aspect of additions to the urban environment. The Urban designer must be careful to avoid equating consideration of the visual dimension of urban design with the consideration of architectural design. Buildings, streets, and space; hard and soft landscaping and street furniture should be considered together, to create drama and visual interest and to reinforce or enhance the sense of place.

The functional dimension of urban design focusing on how places work and how an urban design can make 'better' places; which in detail concerning the use of public spaces and the public / private interfaces; mixed uses and density consideration; environmental design and capital web. The design of public space and public/private interface should consider how people use it which related to social use of space, movement,it shape and edge, visual and aural privacy; and what they need from it which are comfort (which supported by environmental design), relaxation, passive engagement, active engagement, and discovery. Mixed used are important for creating a lively environment, however, it should be done with economic consideration as it will be more difficult to develop, manage and might lessen the value of the investment. With density, the concern is how to protect amenity and provide a livable environment as sometimes it equated with the poor quality environment. While the major capital web consideration in urban design is: the provision of public open space; road and footpath design; parking and servicing; and other infrastructure.

The temporal dimension concerns the temporal or 'time' dimension of urban design which includes three key aspects which are time cycle, continuity and stability; and the management of change. Activities are fluid in space and time, environments are used differently at different times. Facilitating and encouraging the use of urban spaces requires an understanding of the effects of the cycles of day and night, the seasons, and related cycles of activity. At different times of the day and night, the urban environment is perceived and used differently. Although environments relentlessly change over time, a high value is often placed on some degree of continuity and stability. Urban designers need to understand how environments change, what stays the same and what changes over time. They also need to be able to design and manage environments that can accommodate the inevitability of time's passage. Urban design is a massive project which needed quite a lot of time to be finished, it also involves diverse field which might also change over time. Thus it is necessary to consider how to manage the change through three key processes of urban design which are development, control, and communication.

\section{Formal Structure of University's Perimeter at Sumbersari - Gajayana}

The method used to understand the urban informality phenomenon and how it related to its urban design dimension is mapping. In this study, the mapping is not only done as an illustration or to shows territory but as thinking tools to investigate (Dovey, 2014). The information collected through observation which partially utilizing the google maps and street view. The component of formal 


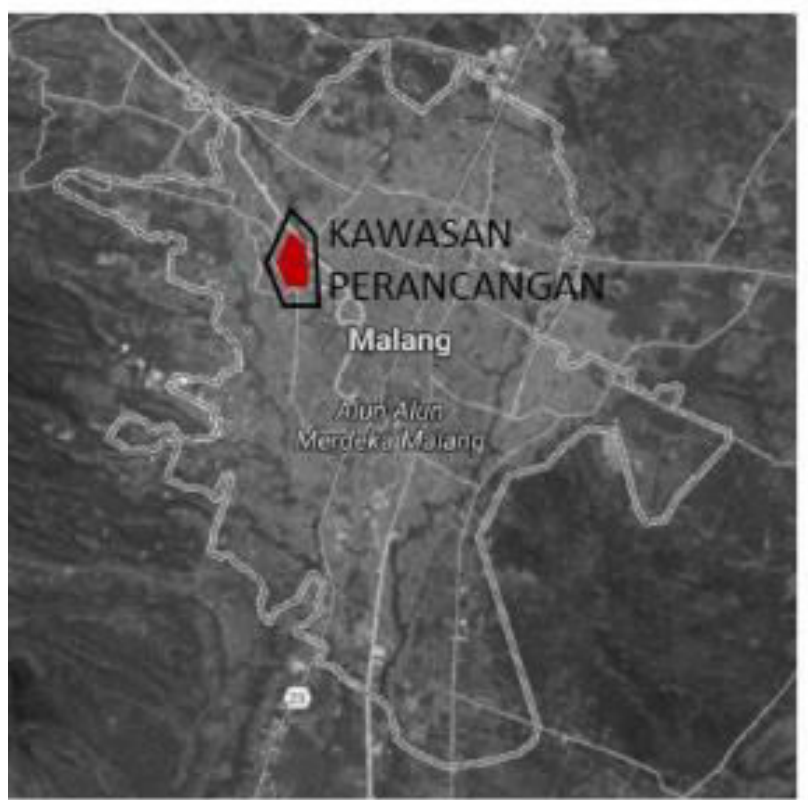

Fig. 5. Site Context.

practices observed and mapped consists of site users, activity and function. While the component of informal practice consists of street vendors and street arts.

Sumbersari - Gajayana street is the main street corridors which connecting the university's perimeter area formed by Brawijaya University at the east, UIN Maliki at the west and ITN at the south. It also connects two local kampongs which are Ketawanggede (the university perimeter of Brawijaya) at the east and Sumbersari (the university perimeter of UIN Maliki and ITN) at the west. The study area is limited to areas affected and formed by the university's activity which is the main street and local street located within the kampong (as shown in figure 2).

The site is part of North Malang which is the center of higher education in Malang and it's highly accessible through public transportation. The main road went through the site also connecting the site with other University's perimeter that becomes student's hotspots which are Bendungan Sigura - Gura, Veteran and MT Haryono Street. Through its local street network, the site also connected through other hotspots which are Sunan Kalijaga and Watugong. Compared to other hotspots, the site actually has a more diverse mix of user and activity, because of the stronger presence of local kampung resident. However, it's currently the most unattractive hotspots for students.
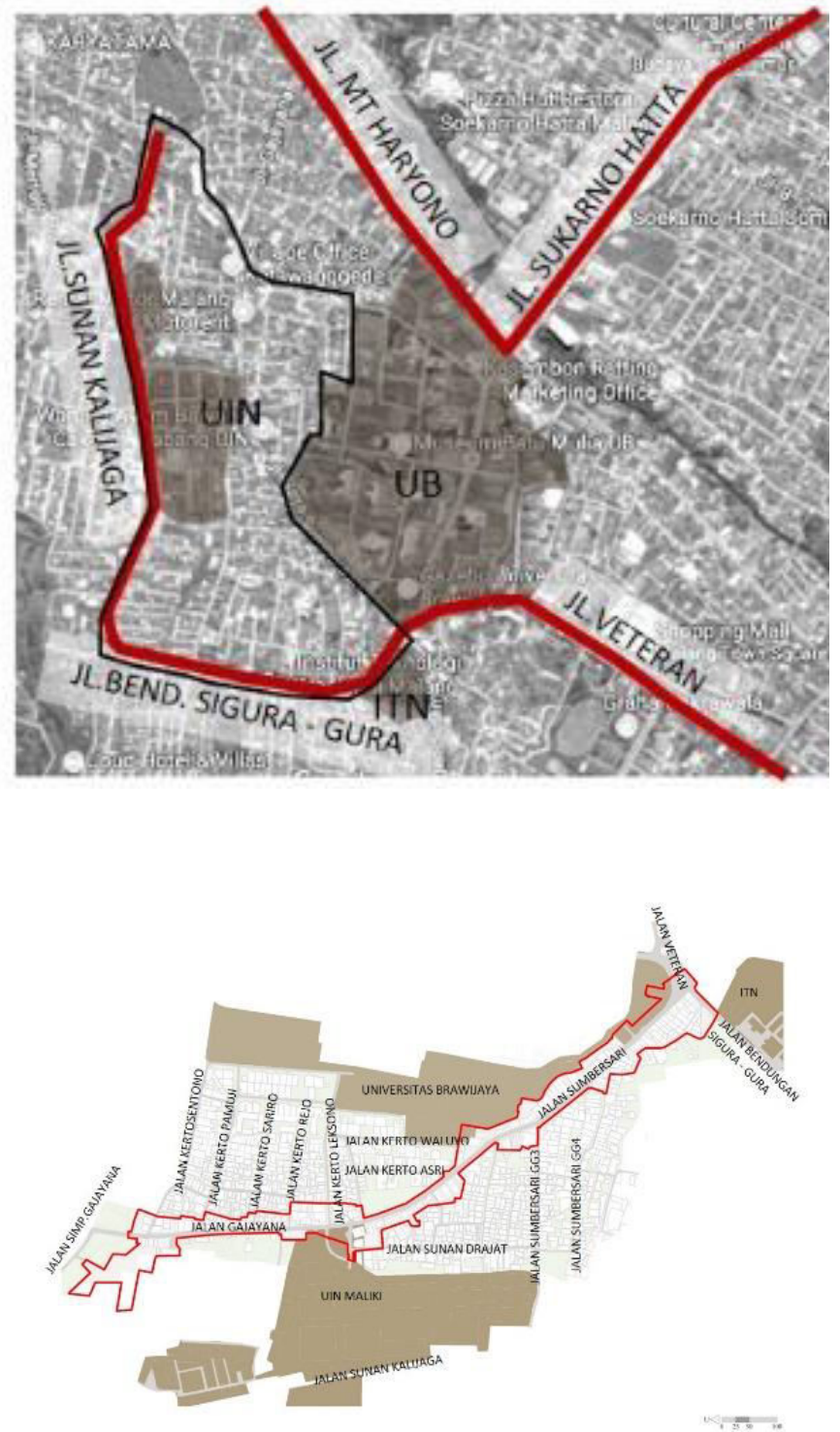

Fig. 6. Study Areas.

The main use for this area is local resident; which also the owner of several formal and informal retails in the area, and the university student consists of mostly Brawijaya and UIN Maliki's students. As Brawijaya grew its students is coming from the wider radius, which includes a student from bigger cities such as Jakarta, Bandung and from cities outside Java. This student demographics change allegedly affected the social dynamic in the site, which then rendered the site unattractive. The functional mix consists of housing, public facilities, retails, consumption and small-scale production. The housing consist of kampong resident's house (which sometimes also provide room for students), boarding house (cost) and boarding house which mixed with a retail function on the first level. The strong presence intense use of public facilities which consist of civic center Kantor kelurahan), kindergarten and elementary school, mosque and health facilities (posyandu). The unique types of retails found within the areas, which are not usually found outside the university perimeter area, are those which provide the student's academic needs such as stationery, photocopy, printing, translation, and data analyzing services and additional study courses. While the most dominant 


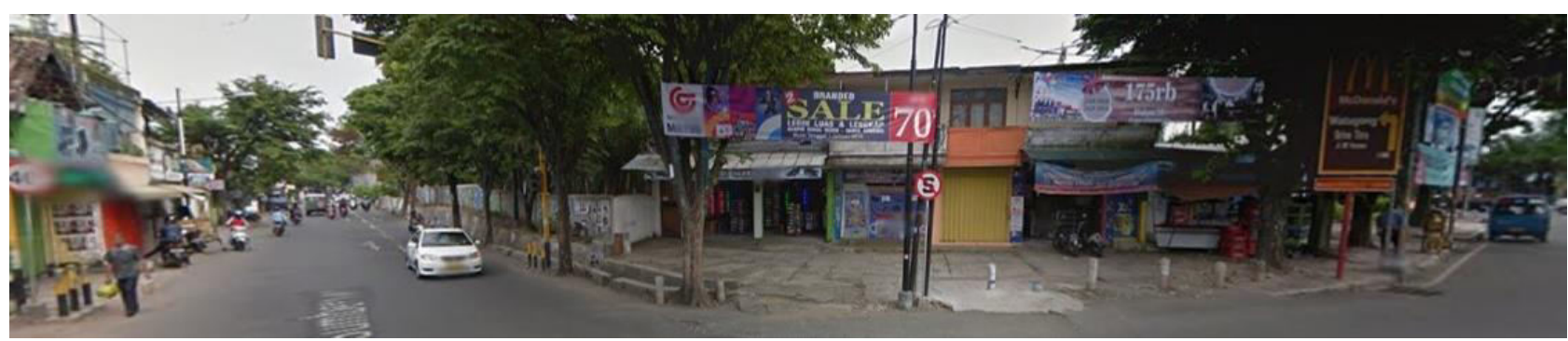

Main Street: Sumbersari Entrance, Right Side Is Entrance To Brawijaya University, Left Side Connected To Bendungan Sigura Gura Street And ITN.

Source: Google Street View, 2016.
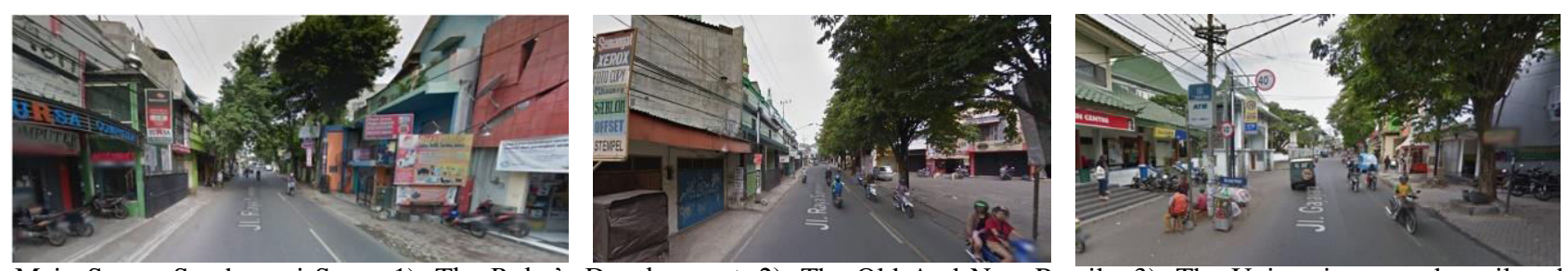

Main Street: Sumbersari Street 1). The Ruko's Development, 2). The Old And New Retails, 3). The University owned retail and privately own retails.

Source: Google Street View, 2016.
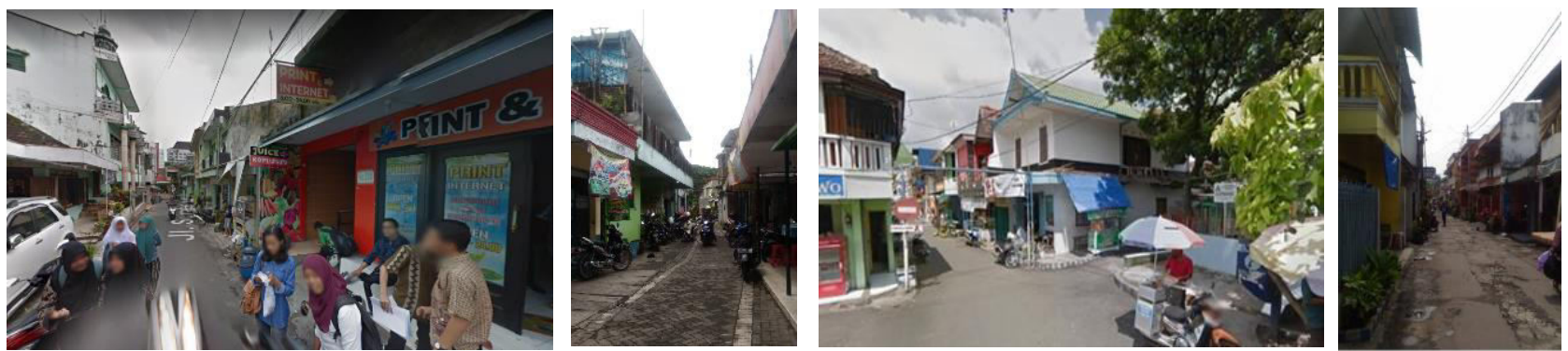

Local Street: 1). Academic related services anc consumption at Sumbersari Gg 3 Street, 2). The Sunan Drajat Alleyway, 3). Academic related Retails at Kertoleksono Street, 4). Local housing and boarding house at Kertosentono Street.

Source: Google Street View, 2016.

Fig. 7. The main and local street within site.

Source: Google Street View, 2016.

function found on the areas are retailed which supplies both students and local residents daily needs such as Toko kelontong and small-scale-home based consumption function such as warung.The small-scale production found on site is consists of food production, tailor services, printing, merchandise production, shoe artisan, and florist. The most dominant production are food production and printing.

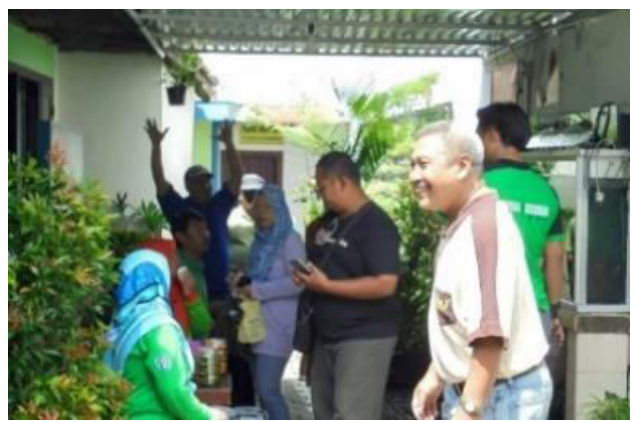

Fig. 8. The Greening Competition Event at Ketawanggede. (Source: http://kelketawanggede.malangkota.go.id, 2016)

While the mix of function showed the entanglement of the students and local residents, the activities do not. There is no shared activity within the site other than brief interaction which only happened between students and the local resident which acted as its landowner. The student's routine activity is showed through the academic's retails available throughout the area, but their other activities such as performances and hangouts are not found within this area. There are also potential university's events and programs, such as the recycle and agripreneur programs form Brawijaya's University and student's events form UIN, which rarely or never done within the site. Most of the student activities are either done in their living space or in university.

The local resident's activity is mostly done utilizing the space of local street and an empty lot. The interaction between residents often found at the local streets, which they consider the extension of their home's terrace. They also conducted several events such as greening competition and historical parade and bazaar. However, most of these activities and events are still not accommodate spatially and mostly done within Local Street. The main road mostly 
consists of retails, further covering the unique characteristic of the kampong behind it.

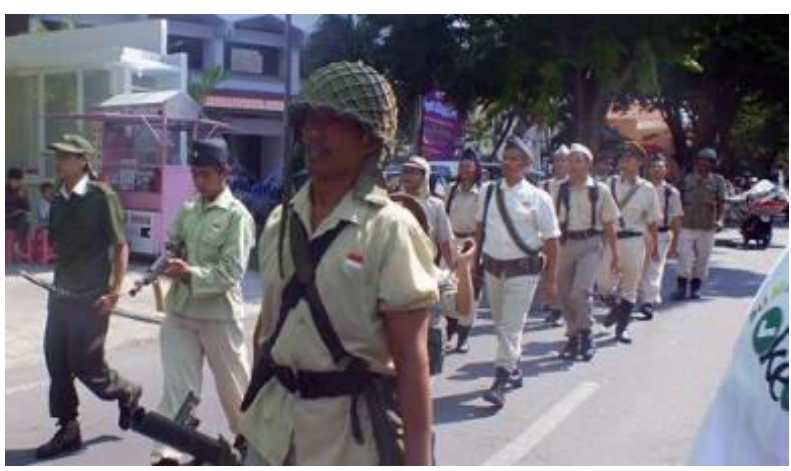

Fig. 9. The Historical Parade.

Source: https://tawangsarikampoengsedjarah.wordpress.com, 2016.

\section{Informal Practices within University's Perimeter at Sumbersari - Gajayana}

Complementing those formal practices, the informal practices found within the site consists of a street vendor and street art. Street vendor found at the site mostly sell food and drink, although there are also small numbers of vendors which sell groceries in the morning, gasoline and newspaper. The types of food sold are mixed of local home-cooked food (such as 'warung nasi', pecel, Soto, sop ayam), specialty food (such as restoran padang, chinese food,rica - rica, siomay bandung, pempek) and cheap student food (nasi lalapan, nasi goreng, nasi ayam). The type of snack sold is consist of desserts such as ice cream, martabak (pancake) and light snack such as 'cilok'. The product is sold and its prices showed the customer it's targeted, which are kids of local resident and university's student. It also shows the cultural diversities of the student and how it exists along with local food.

The dominant typologies found are kiosk and vehicle, although there are also found a table and pavement typologies. The table typologies are not technically using a table to sell but using the shelf. The wall/fence typologies are not found at the site. The fixed type of street vendors found at site mostly attached to local resident's house, utilizing their terrace to sell food and drinks, some developed into part of the housing interface as warung. While the semi-fixed and un-fixed type found at the local street mostly sell vegetables, groceries, and snacks which are the most of products which the fixed type didn't sell. This show how street vendor as informal practices can be developed into formal practices and how both of formal and informal practice can actually can goes along harmonically through some sets of 'informal rule and organization'.

Street art found in the site, based on how it drew consist of two types which are graffiti and mural. The graffiti consisted of those which only to show identity through tagging on storefronts an those which convey protest

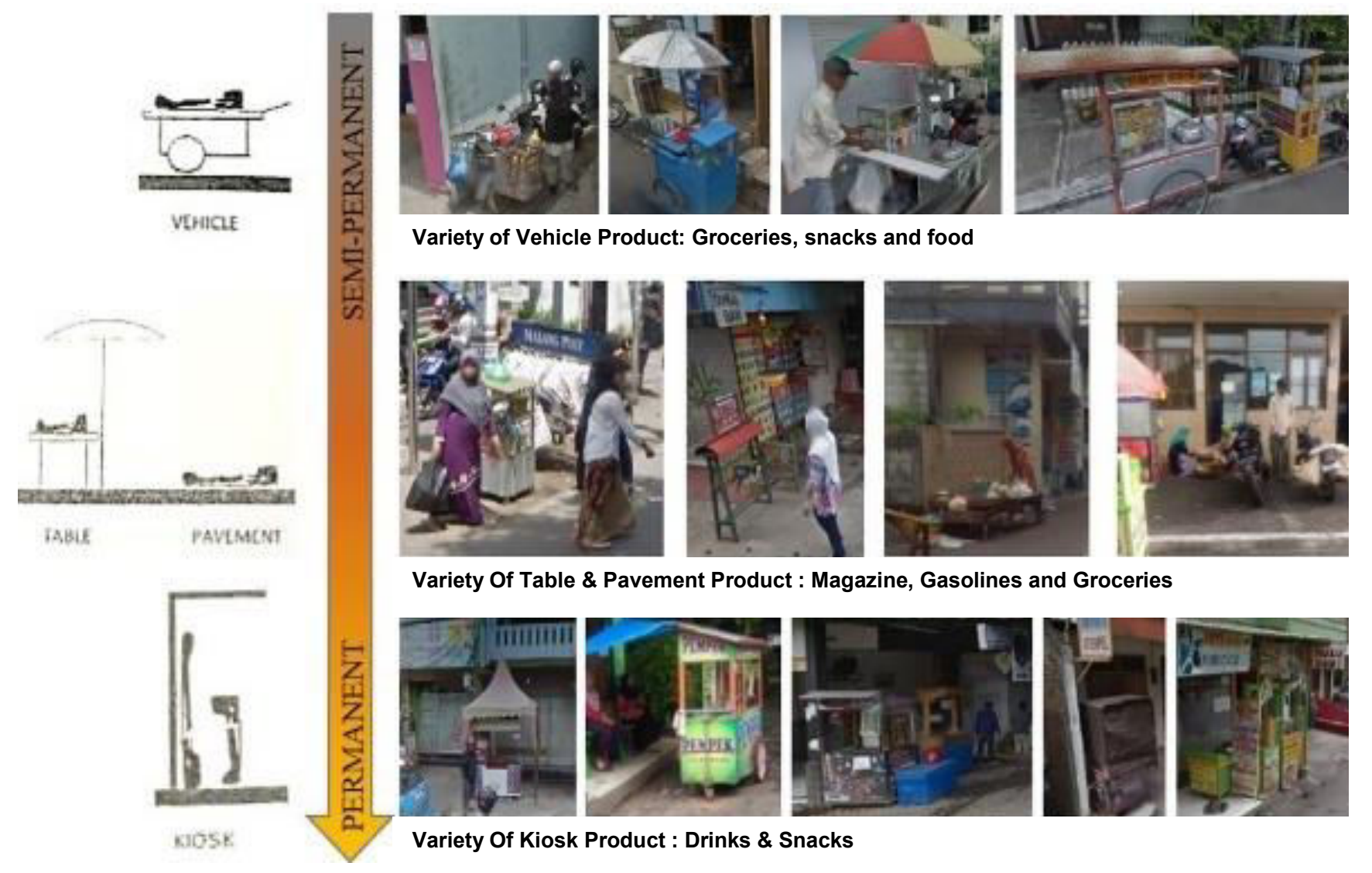

Fig. 10. Typologies of Street Vendors. 


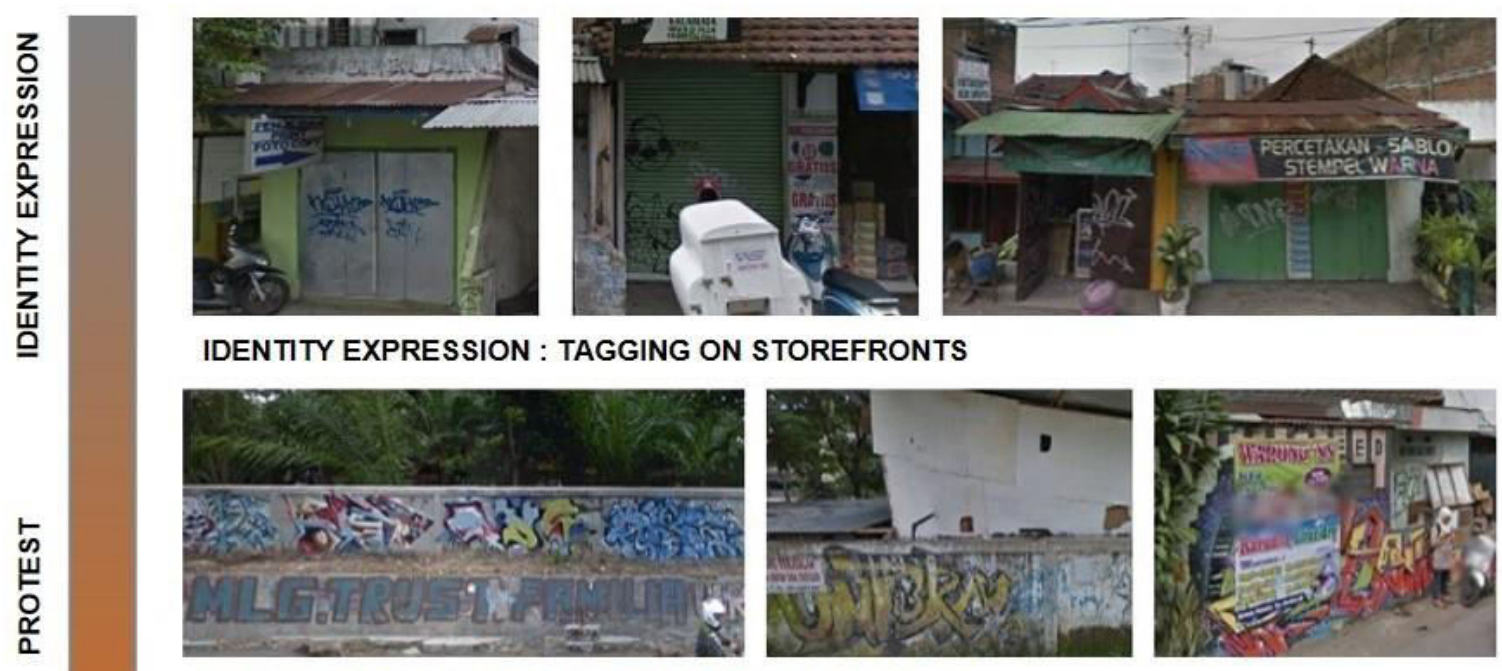

IDENTITY EXPRESSION \& PROTEST: PIECE \& SLOGAN
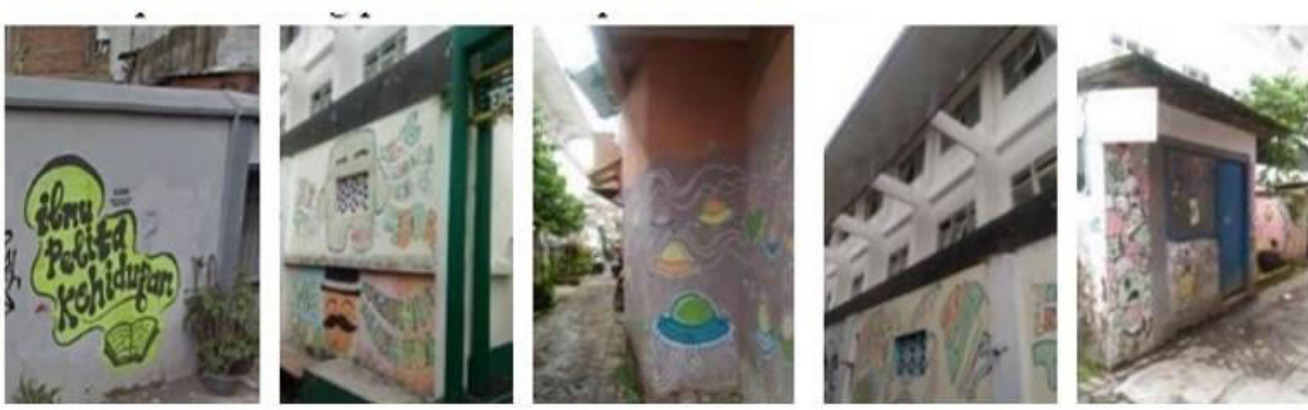

COLLABORATIVE EFFORTS FOR BEAUTIFICATION : MURALS AND SLOGAN

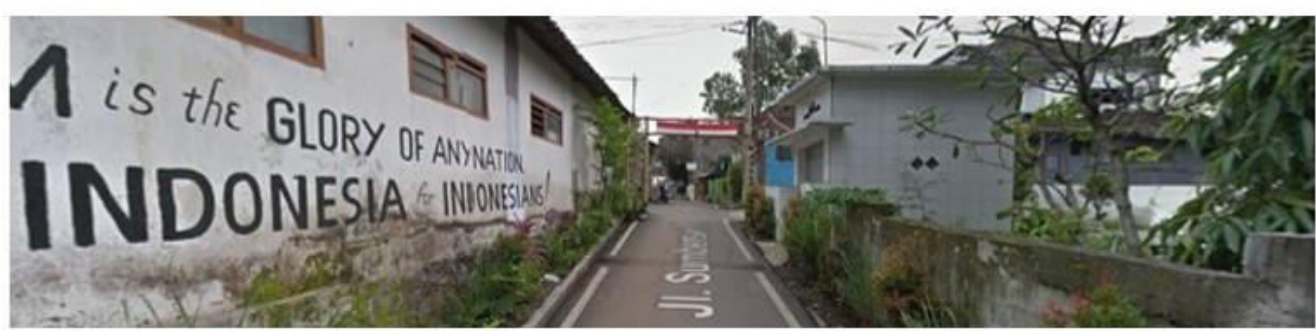

COLLABORATIVE EFFORT TO SUPPORTING LOCAL EVENTS : SLOGAN
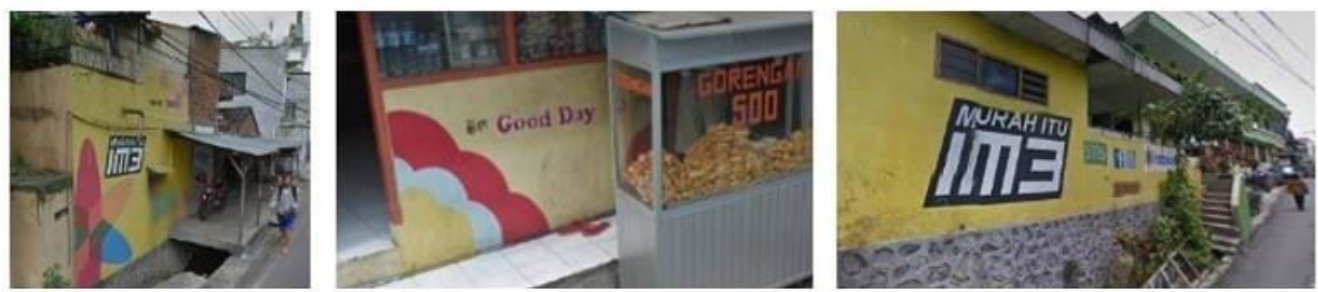

ADVERTISING : TELECOMMUNICATION PROVIDER AND INSTANT COFFEE BRAND

Fig. 11. Typologies of Street Arts.

\section{message.}

One of the message identified was 'Malang sumuk' or roughly translated Malang's daily temperature is becoming hotter. Malang was known for its airy and cool weather, the development of its urban area is causing the lost of urban interaction space, lack of identity and environment issues such as the rise of its temperature. That message was written by one of the biggest street art community in Malang which called themselves Joy O Klan as a form of protest to city's development which degrading the urban identity through the rapid and massive growth Ruko and left them no place to socially interact. As a form of their protest they usually only tagging their community's name to the Ruko wall, but to convey a message which most people can understand they started to write 'Malang Sumuk' (Ferianto, 2015). 


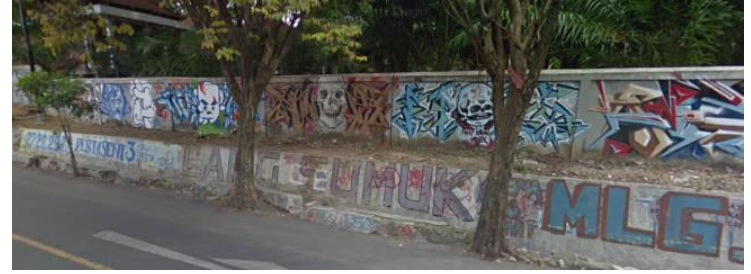

Fig. 12. 'Malang Sumuk' Graffiti by Joy O Klan. Source: Google Street View, 2016.

While the murals found on the site consist of three types based on its motivation and how it made: the collaborative for neighborhood beautification, collaborative to support local events and commissioned murals made to sell and promote products. UIN's architecture faculty had a program called 'Grebeg Arsitektur' which tried to provide an architectural solution for kampong (Tri, 2015). That program resulted in murals along the alleyway connecting UIN entrance with Sumbersari Gg3 Street. This alleyway is where the activity of the UIN's students more intense as it provides academic, daily and tertiary needs from students. The messages they tried to convey through the murals are mostly normative and more directly such as don't do drugs, 'hati-hati di jalan' (be careful on the way) and 'hijaukan kampung kita' (make our kampong green). However there is one message which conveys the assemblage of the neighborhood user and the interrelationship between them which say 'yang lebih tua menghargai yang muda, yang lebih muda menghormati yang lebih tua' (the older generation appreciate the younger generation while the younger generation respect the older generation).

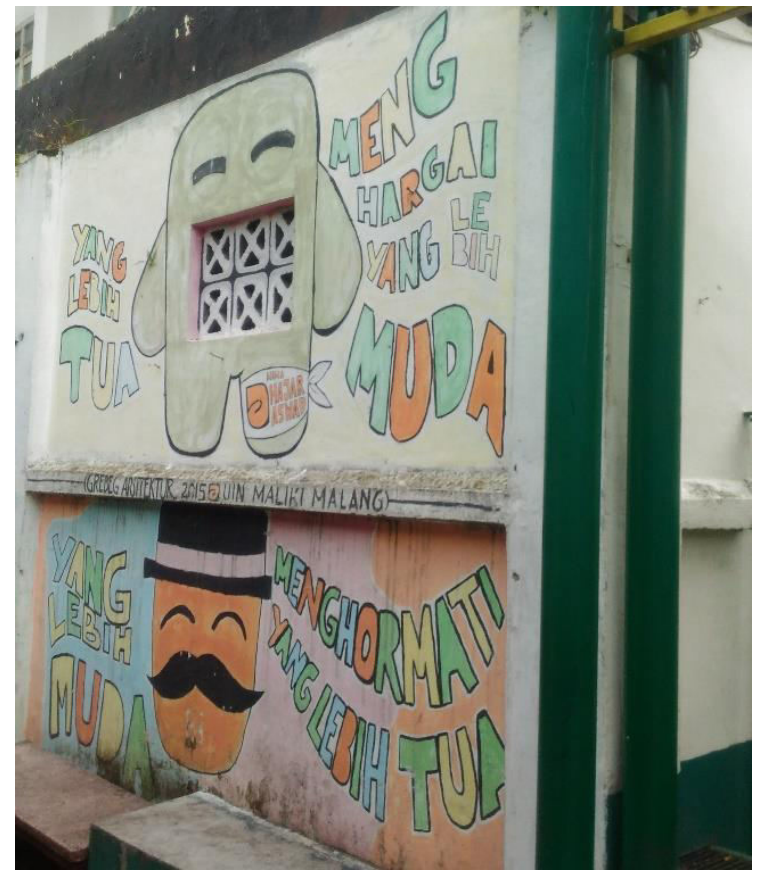

Fig. 13. 'Greek Arsitektur' Murals by Student of Architectural Faculty's UIN Maliki.

The other collaborative murals found are those which support the local events at Sumbersari which are the historical re-enactment parade and bazaar. Most of them consist of slogans written on white painted wall quoting the existing nationalism slogan by influential figure during Indonesia's Independence. They mostly located along the pathway towards the Kantor Kelurahan Sumbersari where the bazaar and historical war theme re-enactment took place. As seen in fig. 7 it showed how the murals complementing the bazaar and war enactment settings.

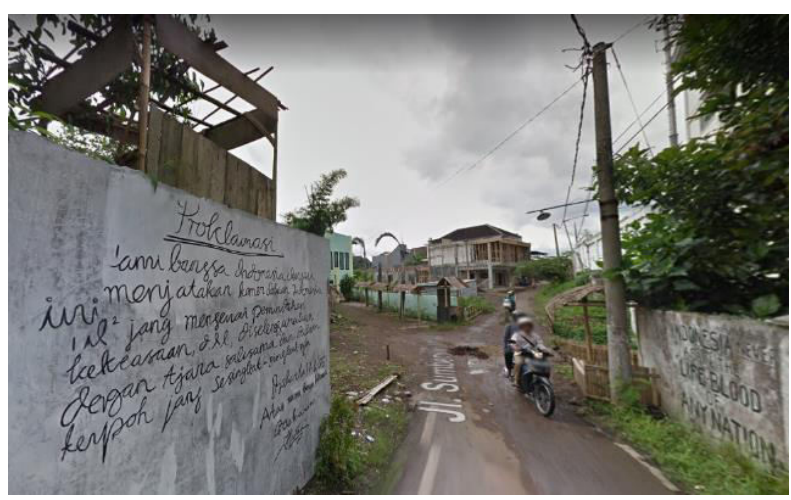

Fig. 14. 'Naskah Proklamasi' along with other slogans and trace of local historical war-themed bazaar.

Source: Google Street View, 2016.

The advertising murals found on site mostly promoting telecommunication vendors and instant coffee brand. Those are a form of wall painting advertising strategies usually done to promote telecommunication vendors, coffee, machine lubricant, lamp, and cigarettes, however, what's found at the site are telecommunication vendor and coffee product. Advertising is done considering its consumer characteristic, thus the type of product advertised on site showed that the site is considered where their potential consumer, which are students, are mostly gathered and doing their activity. While these advertising murals have good visual quality and might contribute to the positive visual quality of its environment, their existence might be associated with the neighborhood characteristics. For example, people might associate some part of the neighbourhood as the 'indosat' street than Kertosentono Street.

All the types of street art found on the site showed how street art as an informal practice is representing its user and complementing its formal practices. To understand more about how formal and informal practice related to its urban area's character, productivity and vitality I will analyze further through its clustering.

\section{Clustering, Alliance, and Association}

Mapping analysis of function within the site found clustering of retail function which is academic and daily needs; consumption and services; and daily and tertiary needs. Academic and daily needs clustering formed by the intensive activity of Brawijaya University's student and Ketawanggede's residents. Consumption and services clustering formed mostly by local retails and UIN's Maliki students. While daily and tertiary needs clustering formed in the parts of the site which located near the intersection which connects the site to another university's hotspots and Malang's retail corridor. 
Within those function clustering, I have also found clustering of activity formed by local residents and university's programs. The clustering of local resident's activity are usually located near or within existing public facility which is the Kantor Kelurahan and it seemed like it related to the function clustering. Greening competition activity is found within academic and daily needs clustering, while historical parade and bazaar were located within consumption and services retail clustering. university's student, by trying to show their roots through historical reenactment.

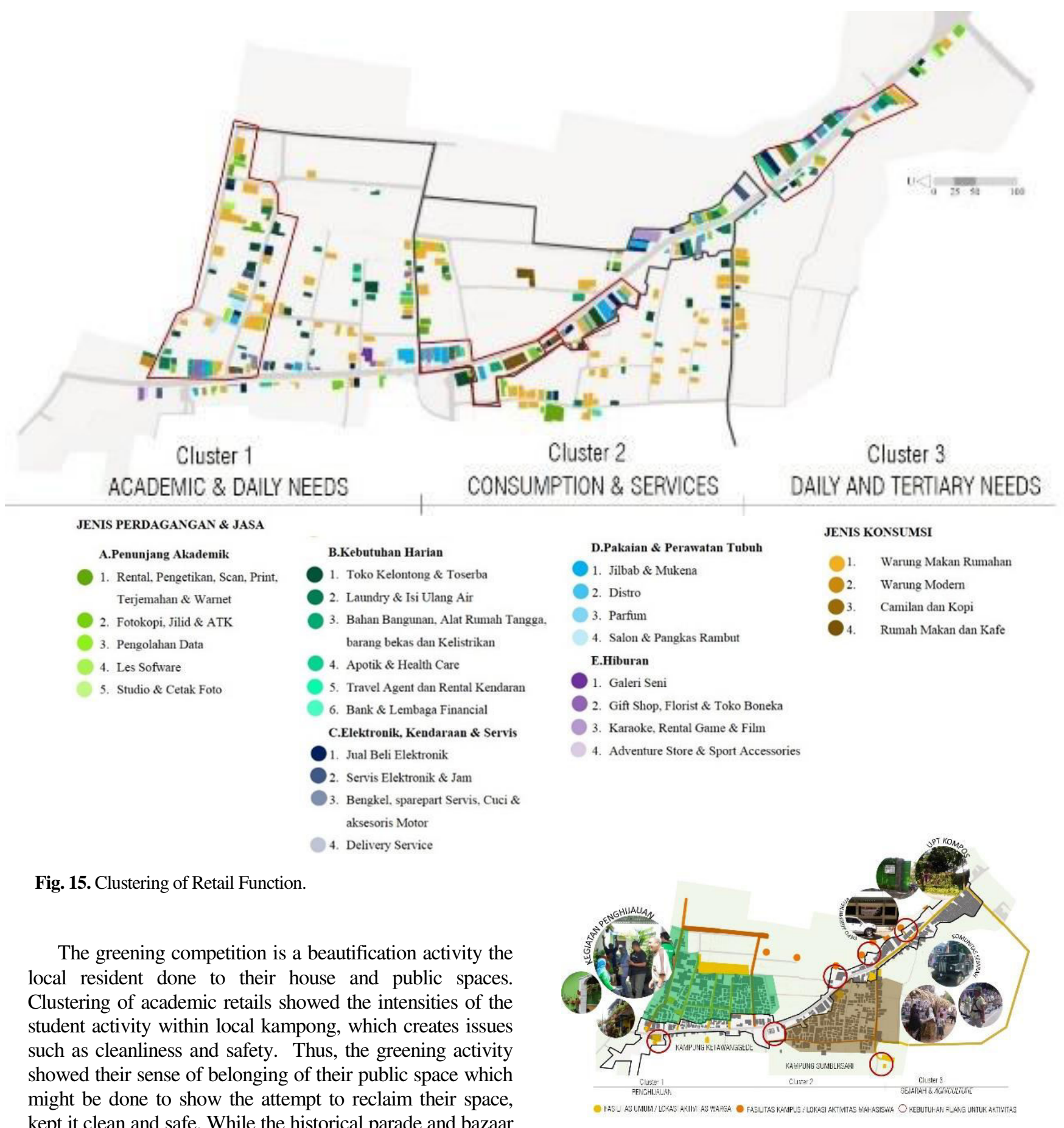

Fig. 16. Clustering of Activities.

Other than local activities, there are also university's programs which located near its perimeter which is recycling 
center and agripreneur, which runs by agriculture faculty of Brawijaya University. Mapping analysis found that along the university boundaries which include the recycling and agripreneur center, also found vandalism and graffiti. Murals were mostly found in the alleyway towards UIN Maliki and along the local streets towards the Sumbersari Civic Center (Kantor kelurahan). While advertising was found scattered along the main road and one local road connecting the main road to Brawijaya University's entrance.

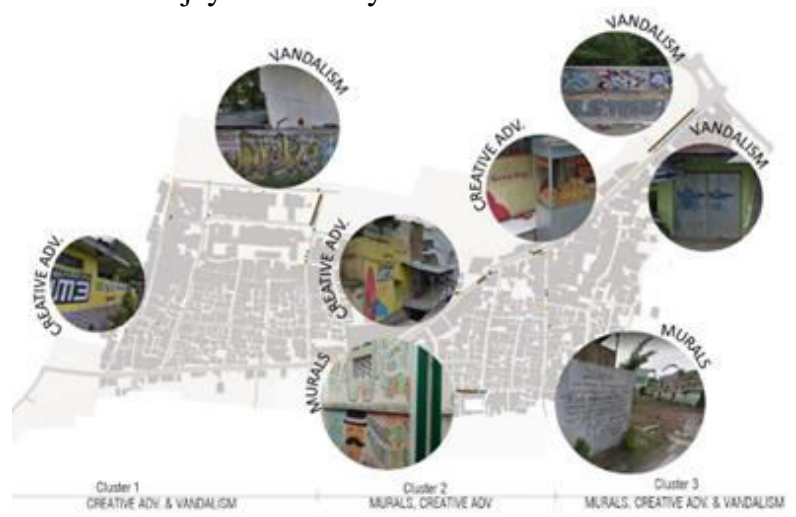

Fig. 17. Clustering of Street Art.

Graffiti or street art quite literally 'takes place' in the sense that it appropriates the street and claims a 'right' to the blank walls of the city and has a captive audience (Dovey, 2016). The typologies and placement of street art in the site are related to the sense of ownership of the place which related to the user in each cluster. While vandalism which found on street front located in cluster 3 can be considered 'bad' and disrupting, it's still unclear whether graffiti a 'good' or a 'bad' thing. Graffiti finds a place in those parts of our cities where identities and practices are open and unfinished. Thus the clustering of graffiti showed that those clusters were still underdeveloped, lack of identities and urban practices.

The clustering of murals showed the resident efforts to reclaim their space by showing their identities through images. Murals found in the alleyway connecting Sumbersari's kampong with UIN Maliki showed the efforts of the students to contribute to their surroundings. It also shows that the boundary between university and its surroundings can be blurred. While murals located near the historical bazaar location showed how street art can be utilized to supports formal activity, which in turn will create a new positive identity for the urban space.

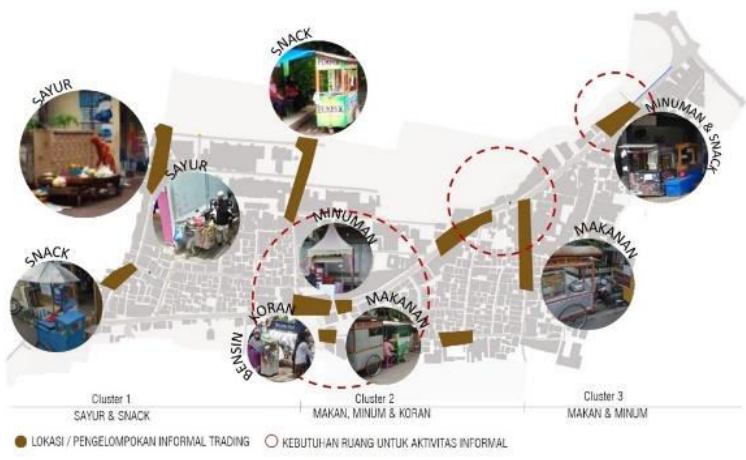

Fig. 18. Clustering of Street Vendor.
The clustering of street vendor also related to its formal clustering which is its user and the functional clustering. Within academic and daily needs clustering and greening activity, the typologies of street vendor found are a kiosk, vehicle, and pavement. The more fixed type of vendor is slowly transitioning into a more formal form of retail selling mostly food and drink, the semi-fix mostly selling vegetables in the morning and the unfixed selling snacks such as ice cream and meatball. These informal organization of street vendors is not found in cluster 2, where both street vendor and local retail are both selling the similar product of food. Although on the main street, where the retails mostly selling clothes, accessories and offering services for motorcycle; the design of the kiosk/vehicle are more elaborate and the product sold was more diverse, including gasoline and newspaper.

Parallel with street art, street vendor clustering also related to cluster identity. Within cluster 3 the street vendor consists of a mostly kiosk with the type of food it sold varied from local / known food such as bakso or nasi goreng up to the newer type of food and/or drink such as kebabs and blended drink. The spread of more modern newer style of food within cluster 2 while also related to its connection to other more developed student hotspots (ITN and Veteran Street) also related to lack of identity the cluster had. Food and drink are the type of product which most street vendors sold because its profits are more certain as people might always need food and/drink.

\section{Urban Dimension of University Perimeter}

Findings on urban informality within Brawijaya and UIN Maliki confirmed that informality is related to the characteristic of its formal structure. While street vendor type might relate to the morphological dimension, its product selection is the response to the identity it's formal structure providing which are the existing retail, activity, and user. However urban informality within settlement in urban perimeter was not just a byproduct of the formal structures, findings confirmed that street vendors can evolve into a more formal form, a kiosk which extended from local resident's house. The strong correlation to a characteristic of the formal structures also presents in the cases of street art. Although urban morphology was considered for placement, the types and message it conveyed is a response to the character of its place which formed by the assemblage of the user and existing activity. It shows how formal and informal practices are both influenced and influencing its formal structure. These findings confirm that informality indeed is part of public life which apparently not occurs beyond the realm of the formal institution as Carmona has stated (2003), but intermeshed with the formal structure (Dovey, 2012). It is a mode of production of urban space that is also its product as the emergent place assemblage (Dovey, 2012). 
Informality within university perimeter showed the diversity of its user and how differences can be bridged over. This showed through informal rule and organization of formal and informal retails at cluster 1 , also through the collaborative efforts on the alleyway murals. The diversity of user creates a diverse perceptual dimension of the urban environment. These manifest through a range of street art found within the site which conveys a wide range of message from showing identity, protest to normative slogans. This street art also was done as a way to counter the 'placelessness' of the urban environment, which caused by the loss of attachment of the university's student to this area. To some parts of the site, the street art is able to reinforce the sense of the place, but still unable to contribute to the visual interest of the whole environment.

University perimeter is formed through the interaction of local resident which use the area for long period of time and students which change periodically. That temporal dimension affected the informal practice more than the formal practice. The function of the university stayed relatively similar within 10 year period, while the informality changes more dynamically. The changes of students will also affect functional dimension of the environment, especially the density. Higher density resulted in the poor quality environment within university perimeter which showed through the lack of comfort for pedestrian and public space on the site.

Urban space is a place of exchange and traffic in people, ideas, and goods (Dovey, 2016). Within university perimeter, there are potential for exchange and spread of ideas and goods through its formal and informal practices. Informal practices might consider urban problems, but this research showed that it actually intermeshed with the formal practice and has the potential for 'making the place' when collaborative efforts are present. The morphological, visual and functional dimension of university perimeter is driven by the social, perceptual and temporal dimension formed by its user and showed through informality. These not only explained why the current efforts in managing informalities in Indonesia were rarely succeeded but also shows how it might works which is as stated by Dovey (2016) through tolerance and recognition. It is necessary to recognize the social, perceptual and temporal dimension of informality; to consider which morphological, visual and functional dimension of it tolerable concerning public good.

\section{References}

Arifrahara, G., Haswanto N, \& Wahjudi D. (2013). Analisa Karakteristik Visual dan Strategi Visual Iklan Wall Painting Studi Kasus Iklan Wall Painting Empat Operator Telekomunikasi Nasional, Wimba Jurnal Komunikasi Visual \& Multimedia. Vol. 5 No.1 Tahun 2003. Retrieved from http://jurnalwimba.com

Bappeda Kota Malang. (2016, 10 11). Ringkasan Eksekutif Rencana Induk Jaringan Jalan Kota Malang. Retrieved from Bappeda Kota Malang: http://bappeda.malangkota.go.id

Carmona, M and Tiesdell S. (2003), Public Spaces, Urban Spaces.Oxford : Architectural Press.
Carmona, M and Tiesdell S. (2007), Urban Design Reader.Oxford: Architectural Press.

Dovey, K. (2010). Informal urbanism and complex adaptive Assemblage, International Development Planning Review, $34 \quad$ (4) 2012 pp 349 - 367. doi:10.3828/idpr.2012.23

Dovey, K. (2016). Urban Design Thinking: A Conceptual Toolkit. New York: Bloomsbury Academics.

Dovey, K., \& S., \&. W. (2015). Creative Multiplicities: Urban Morphologies of Creative Clustering. Journal of Urban Design Vol 20 no 1, 52 - 74. DOI: 10.1080/13574809.2014.972346

Dovey, K., Wollan, S. \& Woodcock I. (2012) Placing Graffiti: Creating and Contesting Character in Inner-city Melbourne, Journal of Urban Design, 17:1, 21-41, DOI: 10.1080/13574809.2011.646248

Ferianto, G.E. (2015). Street Art: Representasi Identitas Dan Kritik Social (Studi Kasus pada Generasi Baru Street Art Joy O Klan Kota Malang). Retrieved from Jurnal Mahasiswa Sosiologi http://jmsos.studentjournal.ub.ac.id/index.php/jmsos/arti cle/view/76

Garis Putih (2016, October, 20). Graffitude - 10 Years Ngaco Fams [Video file]. Retrieved from https://www.youtube.com/watch?v=HdzErhSai50

Hamid, A. [Abdul Hamid]. (2016, April 25). Festival Mural \#Earth Day Uin Maliki Malang [Video file]. Retrieved from https://www.youtube.com/watch?v=-KqchOdMrI

Homes and Communities Agency the UK. (2015, 09 12). Guidance Urban Design Compendium. Retrieved from Gov.UK: https://www.gov.uk/government/publications/urbandesign-compendium

Lang, J. (2005). Urban Design: A Typology Of Procedures And Products. Oxford: Architectural Press

Porter. L et all.(2011) Informality, the Commons and the Paradoxes for Planning: Concepts and Debates for Informality and Planning.Planning Theory \& Practice, 12:1, 115-153, . DOI: 10.1080/14649357.2011.545626

Syrian, Y. [Syidan Yusuf]. (2016, August 28). Karnaval sumbersari malang [Video file]. Retrieved from https://www.youtube.com/watch?v=leD8rvAYtLg

Tri, A. [Agus Tri]. (2015, August 22). Grebek Arsitektur 2015 UIN Maliki Malang Sumbersari bermural dan berkebun (review) [Video file]. Retrieved from https://www.youtube.com/watch?v=C4iB9nGEYBQ

Yatmo, Y.A \& Atmodiwirjo, P. (2011) "Understanding the Metaspaces of Street Vendor in the Cities: Temporality, Strategies, and Tactics." Originally published in the Proceedings of 10th International Conference on Quality in Research (QIR), Faculty of Engineering, University of Indonesia, 4-6 December 2007. Retrieved from http://arsitektur.net/doctorwho/wpcontent/uploads/2011_vol_05_03-04_Understandingthe-Metaspaces.pdf 
Yatmo, Y.A. (2008) Street Vendors as 'Out of Place' Urban Elements, Journal of Urban Design, Vol. 13. No. 3, pp 387-402. DOI: 10.1080/13574800802320889 